\title{
Correlation between circulating leptin and luteinizing hormone during the menstrual cycle in normal-weight women
}

\author{
Tomi Teirmaa, Virve Luukkaa, Juha Rouru, Markku Koulu and Risto Huupponen \\ Department of Pharmacology and Clinical Pharmacology, University of Turku, Turku, Finland \\ (Correspondence should be addressed to V Luukkaa, Department of Pharmacology and Clinical Pharmacology, University of Turku, \\ Kiinamyllynkatu 10, FIN-20520 Turku, Finland)
}

\begin{abstract}
Objective: Leptin is the hormonal product of the $o b$ gene. It is expressed in adipocytes and participates in the regulation of food intake and metabolism. Since leptin also seems to signal metabolic information to the reproductive system, we studied the association between reproductive hormones and plasma leptin in normal-weight young women.

Design: Eight young women with normal menstrual cycles (body mass index (BMI) $21.2 \pm 1.6 \mathrm{~kg} / \mathrm{m}^{2}$ ) and eight young women using hormonal contraception (BMI $21.4 \pm 1.1 \mathrm{~kg} / \mathrm{m}^{2}$ ) were studied. Furthermore, six women with normal menstrual cycles and no hormonal therapy (BMI $20.7 \pm 1.2 \mathrm{~kg} / \mathrm{m}^{2}$ ) were studied around the time of the anticipated ovulation.

Methods: Serum leptin, estradiol, progesterone and luteinizing hormone (LH) concentrations were measured with radioimmunoassays.

Results: Serum leptin concentrations were similar at the beginning of the cycle, at the time of the anticipated ovulation and at the end of the menstrual cycle $(10.2 \pm 7.1,10.7 \pm 7.0$ and $11.8 \pm 6.9 \mu \mathrm{g} / \mathrm{l}$ respectively). There was an association between leptin and LH concentrations $(r=0.37, P<0.01)$ when values recorded during different time points during the cycle were plotted with each other. There was no change in serum leptin in samples taken at different times of the cyclic treatment with an oral contraceptive. There was no significant difference in mean serum leptin concentrations between women using oral contraceptives and women with no hormonal therapy. Conclusions: There is a link between serum leptin and LH concentrations during the menstrual cycle. Variations in circulating estrogen and/or progesterone concentrations have no major influence on circulating leptin in young female subjects.
\end{abstract}

European Journal of Endcrinology 139 190-194

\section{Introduction}

Leptin is a hormonal product of the adipose tissue. It seems to mediate the satiety signal from peripheral fat to the central nervous system. Increasing body fat content results in the elevation of circulating leptin concentrations $(1,2)$. Leptin was originally characterized in obese $o b / o b$ mice that have a mutation of the $o b$ (leptin) gene leading to lack of active leptin (3). Obese female $o b / o b$ mice are infertile due to a defect in the feedback regulation of the hypothalamic-pituitary axis (4). Their early sexual development is normal, but ovulation and estrous cycles never occur in these animals (5). However, administration of recombinant human leptin to these mice corrects their sterility (5), supporting the existence of significant interactions between leptin and the reproductive system.

Leptin is present in follicular fluid and can induce a biological response in ovarian cells, suggesting that leptin may have a direct effect on the human ovary (6). Both long and short isoforms of leptin receptors are expressed in the ovary (6). Thus, information on body fat stores may be transferred to the reproductive organs through leptin. On the other hand, gonadal hormones may regulate plasma leptin. The plasma leptin concentration is higher in pre- than in postmenopausal women, and males have lower leptin concentrations than females, even when corrected for differences in body composition (7).

To see whether there are changes in serum leptin concentrations during the normal menstrual cycle, we measured serum leptin concentrations at different time points during the cycle in young healthy females not using any hormone therapy and in women regularly taking oral contraceptives.

\section{Materials and methods}

\section{Subjects and study design}

Three groups of young healthy non-smoking female volunteers with regular menstrual cycles between 27 
Table 1 Demographic characteristics of the study groups. Values are means \pm S.D.

\begin{tabular}{lcccc}
\hline & Age (years) & Weight $(\mathrm{kg})$ & Height $(\mathrm{m})$ & BMI $\left(\mathrm{kg} / \mathrm{m}^{2}\right)$ \\
\hline Group I $(n=8)$ & $23.5 \pm 2.1$ & $59.6 \pm 4.3$ & $1.67 \pm 0.04$ & $21.2 \pm 1.6$ \\
Group II $(n=8)$ & $23.1 \pm 1.7$ & $59.6 \pm 4.5$ & $1.67 \pm 0.08$ & $21.4 \pm 1.1$ \\
Group III $(n=6)$ & $24.2 \pm 1.8$ & $57.2 \pm 3.2$ & $1.66 \pm 0.02$ & $20.7 \pm 1.2$ \\
\hline
\end{tabular}

and 30 days were included in the study. They all had a body mass index (BMI) between 20 and $25 \mathrm{~kg} / \mathrm{m}^{2}$ and they did not take any regular medication (except oral contraceptives when indicated). The demographic characteristics of the volunteers are presented in Table 1. All the participants gave written informed consent to participate. The protocol was approved by the Joint Ethical Committee of the University of Turku and Turku University Central Hospital.

The first group (group I) consisted of eight volunteers not using any hormonal contraception. Three blood samples were collected at different time points during the menstrual cycle; one sample between the 2nd and 5 th day, another on the 14 th or 15 th day and the third between the 24th and 26th day of the cycle.

The second group (group II) consisted of eight volunteers using hormonal contraception on a regular basis. They all had used an oral contraceptive containing $30 \mu \mathrm{g}$ ethinylestradiol and $75 \mu \mathrm{g}$ gestoden (Femoden, Schering AG, Berlin, Germany) for at least 6 months. The tablets were taken daily from the 1st day after menstruation to the 21st day when a seven-day break was introduced. Four blood samples were taken in these subjects: one on the 7 th or 8 th day after initiation of drug intake, another between the 19th and the 21st day, the third between the 5th and 7th day of the drugfree period and the fourth sample again on the 7 th or 8 th day of the following cycle.

The third group (group III) was included to get accurate information from the time around the anticipated ovulation during which rapid changes in gonadotropin secretion take place. This group included six volunteers not using any medication. Five blood samples were collected on five successive days (between the 12th and the 16th days of the cycle) in this group. The anticipated time of ovulation was calculated as the first bleeding day minus 14 days.

\section{Methods}

All blood samples were taken by venipuncture between 0800 and $1000 \mathrm{~h}$ after an overnight fast. The volunteers had at least $15 \mathrm{~min}$ rest in the sitting position before the samples were taken from a large forearm vein. Serum was promptly separated and kept frozen at $-70^{\circ} \mathrm{C}$ until analyzed. Serum leptin was measured with a human leptin radioimmunoassay (RIA) kit (Linco Research, Inc., St Charles, MO, USA). The interassay coefficients of variation were $6.5 \%$ at a mean leptin concentration of $2.9 \mu \mathrm{g} / \mathrm{l}$ and $9 \cdot 9 \%$ at a mean concentration of $14.5 \mu \mathrm{g} / \mathrm{l}$. Serum estradiol (Spectria Estradiol RIA, Orion Diagnostica, Espoo, Finland), progesterone (Spectria Progesterone RIA, Orion Diagnostica) and luteinizing hormone (LH) (Spectria LH IRMA, Orion Diagnostica) were measured with commercially available kits. Protocols given by the manufacturers were strictly followed in all analyses.

\section{Statistics}

Analysis of variance for repeated measures design was used to compare hormone concentrations in serum at different time points during the cycle. The results are expressed as means \pm S.D. BMI was calculated by dividing body weight by height ${ }^{2}$. A $P$ value less than 0.05 was considered statistically significant. The calculations were performed with Systat 5.0 software (Systat Inc., Evanston, IL, USA).

\section{Results}

In women with normal menstrual cycles and no hormonal therapy (group I), serum leptin concentrations were similar at the beginning of the cycle, around the time of the anticipated ovulation and at the end of the cycle $(F=0.69, P=0.52$, ANOVA for repeated measures, Table 2). Expected changes in the gonadal hormones were seen, as evidenced by significantly higher serum progesterone $(\mathrm{F}=10.0, \quad P=0.002$, ANOVA followed by paired $t$-test) and estradiol $(\mathrm{F}=4.03, P=0.041)$ concentrations during the luteal phase compared with values during the first half of the cycle. Serum LH peaked at mid cycle, although differences between the three time points of the cycle were not statistically significant $(\mathrm{F}=2.72, P=0.11)$.

In women using oral contraception (group II), serum leptin also remained unchanged throughout the cycle $(\mathrm{F}=1.62, P=0.22$, Table 2). Furthermore, mean serum leptin concentrations were not different from those recorded in subjects not using any hormonal contraception $(\mathrm{F}=0.01, P=0.91$, ANOVA $)$. Serum progesterone concentrations were constantly low during the cycle, and they did not differ from each other $(\mathrm{F}=0.94, P=0.44)$. Similarly, serum estradiol and LH were low during the contraceptive intake, although estradiol, in particular, increased during the treatment-free period. When all measurements were pooled together, mean serum estradiol $(\mathrm{F}=40.42$, 
Table 2 Mean ( \pm S.D.) serum hormone concentrations in groups I and II.

\begin{tabular}{|c|c|c|c|c|c|}
\hline Group & Time of cycle & Leptin $(\mu \mathrm{g} / \mathrm{l})$ & LH (IU/I) & $\begin{array}{l}\text { Progesterone } \\
\underset{(\mu \mathrm{mol} / \mathrm{l})}{ }\end{array}$ & $\begin{array}{c}\text { Estradiol } \\
(\mathrm{pmol} / \mathrm{l})\end{array}$ \\
\hline 1 & $\begin{array}{l}\text { Day } 2-5 \\
\text { Day } 14-15 \\
\text { Day } 24-26\end{array}$ & $\begin{array}{l}10.2 \pm 7.1 \\
10.7 \pm 7.0 \\
11.8 \pm 6.9\end{array}$ & $\begin{array}{r}5.3 \pm 1.1 \\
11.4 \pm 9.5 \\
5.5 \pm 2.5\end{array}$ & $\begin{array}{c}2.0 \pm 1 \\
6.6 \pm 6.1 \\
25.8 \pm 18.3\end{array}$ & $\begin{array}{l}143 \pm 78 \\
399 \pm 327 \\
511 \pm 272\end{array}$ \\
\hline II & $\begin{array}{l}\text { Day } 7-8 \text { after initiation of a new period of contraceptive use } \\
\text { Day } 19-21 \text { of contraceptive use (end of hormone treatment period) } \\
\text { Day } 5-7 \text { of the hormone-free period } \\
\text { Day } 7-8 \text { after initiation of the next period of contraceptive use }\end{array}$ & $\begin{aligned} 11.9 & \pm 4.8 \\
11.0 & \pm 4.7 \\
9.7 & \pm 4.7 \\
10.0 & \pm 4.2\end{aligned}$ & $\begin{array}{l}3.4 \pm 1.5 \\
1.6 \pm 0.4 \\
4.4 \pm 1.9 \\
4.0 \pm 2.5\end{array}$ & $\begin{array}{l}1.5 \pm 0.4 \\
1.4 \pm 0.5 \\
3.4 \pm 5, .7 \\
1.6 \pm 0.5\end{array}$ & $\begin{array}{l}30 \pm 13 \\
31 \pm 6 \\
131 \pm 94 \\
32 \pm 9\end{array}$ \\
\hline
\end{tabular}

$P<0.001)$, progesterone $(\mathrm{F}=16.03, P=0.001)$ and LH concentrations $(\mathrm{F}=10.66, P=0.006)$ were significantly lower in subjects using oral contraception than in those not on hormonal therapy.

In the third group, the mid cycle serum hormone levels were followed on a day-to-day basis. Mean plasma progesterone concentration increased successively from the 12 th day of the cycle $(4.1 \pm 3.7 \mu \mathrm{mol} / \mathrm{l})$ to the 16 th day $(20.4 \pm 19.3 \mu \mathrm{mol} / \mathrm{l}, \mathrm{F}=3.98, P=0.016)$, whereas mean serum estradiol remained unchanged $(\mathrm{F}=0.38$, $P=0.82)$. Similarly, mean serum leptin $(F=0.80$, $P=0.54)$ and $\mathrm{LH}(\mathrm{F}=0.55, P=0.70)$ concentrations did not change. Since the elevation in serum LH at the time of ovulation is a rapid, short-lasting event occurring on varying days in different individuals, the daily mean values do not adequately reflect the day-today changes. Therefore, serum LH concentrations measured at different time points during the cycle in subjects not receiving hormonal treatment were plotted with concomitantly measured leptin levels. A significant correlation $(r=0.37, P<0.01, n=52)$ existed between serum leptin and LH concentrations, but no correlation was found when similar plots were constructed between serum leptin and progesterone $(r=-0.04)$ or leptin and estradiol $(r=0.16)$. To account for individual variability and different timing of hormone peaks, the relative individual changes in serum leptin, LH, progesterone and estradiol concentrations were also calculated during the mid cycle, by dividing the hormone concentrations on days 13-16 with that on day 12. A significant correlation existed between the relative changes in serum leptin and LH $(r=0.45$, $P<0.05, n=23$, Fig. 1) but not between corresponding changes in serum leptin and estradiol $(r=0.20)$ or leptin and progesterone $(r=0.11)$.

\section{Discussion}

Numerous studies have demonstrated that female subjects have higher levels of circulating leptin than males (8-13). Furthermore, leptin concentration is higher in premenopausal than in postmenopausal women $(7,14)$. Adolescent girls have higher serum leptin concentrations than boys and circulating leptin concentrations are higher before than after puberty $(15,16)$. A gender difference exists also in the regional distribution of leptin expression: the subcutaneous-toomental fat ratio of leptin expression is markedly higher in women than in men (17). Thus, gender seems to be an important determinant of leptin homeostasis but the mechanisms mediating this effect are still obscure.

Data from animal experiments suggest that gonadal steroids might modulate leptin expression. In isolated mature rat adipocytes, $17 \beta$-estradiol increased leptin release $(18,19)$. Eight weeks after ovariectomy, leptin expression was reduced in subcutaneous and retroperitoneal white adipose tissue in the rat; the expression was increased again after estrogen replacement therapy (14).

Hardie et al. (20) found circulating leptin concentration to be associated with the menstrual phase. They recorded peak leptin concentrations during the luteal phase, together with a coinciding elevation of serum progesterone (20). However, the blood samples were not collected at a specific time of the day, which may have affected the results. Leptin secretion exhibits a circadian pattern, serum concentrations steadily increasing from a nadir in the morning to peak concentrations after midnight $(21,22)$. Therefore, the timing of the blood sampling is a critical issue. Tataranni et al. (23) studied plasma leptin during the luteal phase of the menstrual

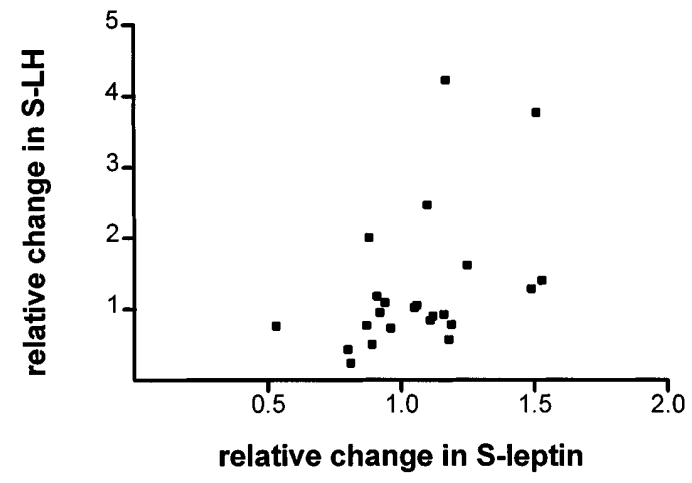

Figure 1 The association between the relative changes in serum (S) leptin and LH concentrations in samples collected around the anticipated time of ovulation $(r=0.45, P<0.05, n=23)$. 
cycle and compared the concentrations with those obtained in amenorrheic subjects. Consistent with our findings, they found no association between plasma leptin concentration and menstrual function after adjusting plasma leptin for percentage body fat.

When studying serum leptin during the menstrual cycle in humans, Shimizu et al. (14) found serum leptin to be higher during the luteal than during the follicular phase of the cycle. However, although they found the difference to be statistically significant, it was small in magnitude (mean values during luteal and follicular phases were 12.2 and $9.2 \mu \mathrm{g} / \mathrm{l}$ respectively). In our study also, a small insignificant trend (about 1.25-fold elevation) to higher values at the end of the cycle was seen when compared with the first days of the cycle (Table 2). A variation of this magnitude may, however, represent a random event. Comparing serum leptin concentrations measured at two physiologically identical time points one month apart in the contraceptive group revealed an identical difference: apparently 1.25fold higher leptin levels were seen at the beginning of the first cycle compared with the beginning of the following cycle. When compared with over 3.5-fold elevation in serum estradiol and about 13-fold elevation in serum progesterone during the same cycle, the 1.25fold insignificant elevation in serum leptin strongly suggests that neither estradiol nor progesterone have a major impact on serum leptin concentrations during the menstrual cycle.

In the subjects using oral contraceptives, endogenous estradiol and progesterone levels were suppressed, as expected. The contraceptive preparation contained $30 \mu \mathrm{g}$ ethinylestradiol, a potent oral estrogen, and $75 \mu \mathrm{g}$ gestoden. Clinical studies have demonstrated that gestoden has strong progestogenic, antiestrogenic and antigonadotropic effects but, at doses used in combination with ethinyl estradiol for contraception, its androgenic activity is negligible $(24,25)$. Therefore, the combination of ethinylestradiol and gestoden can be characterized as an estrogen-dominant formulation (24). No significant changes in circulating leptin were seen in subjects using contraceptives and the mean leptin concentrations did not differ compared with subjects not using any hormonal medication. These findings further strengthen the conclusion that, at least in young female subjects, variations in estrogenic and/ or progestogenic tone will not have a major influence on circulating leptin.

The effects of high estrogen concentrations on leptin were explored in a study with middle-aged premenopausal women using no oral contraceptives, and in postmenopausal women either using or not using postmenopausal hormone replacement therapy. Leptin concentrations were not significantly different among the three groups (26), and in elderly women aged 6072 years, hormone replacement therapy for 11 months had no effect on circulating leptin (26). These findings are in accordance with our results indicating that changes in circulating estrogen due to hormonal therapy are not likely to affect serum leptin.

Besides gonadal steroids, a number of hypothalamic factors may also participate in the regulation of leptin secretion. According to animal experiments, chronic intracerebroventricular infusion of neuropeptide $\mathrm{Y}$ (NPY) increases leptin production in the white adipose tissue by a mechanism probably mediated through increased insulinemia (27). The distribution of NPYproducing neurons in the nucleus arcuatus of the hypothalamus is different in male and female rats (28). In addition, leptin itself may affect reproductive functions and secretion of sexual hormones. In animal studies, very low concentrations of leptin stimulate in vitro the release of luteinizing hormone-releasing hormone from hypothalamic explants as well as follicle-stimulating hormone $(\mathrm{FSH})$ and $\mathrm{LH}$ release from pituitary in the rat; in vivo leptin injected into the third ventricle increases plasma LH (29).

Female puberty has been reported to be associated with increased serum leptin in obese as well as in lean children (16). Garcia-Mayor et al. have studied pubertyrelated changes in leptin in relation to gonadal hormones, LH and FSH in normal children (30). Serum leptin was elevated before corresponding elevations in other reproductive hormones related to puberty took place. Licinio et al. (31) recently reported that release patterns of leptin and $\mathrm{LH}$ are synchronized. At night, as leptin levels peak, the pulsatility profile of LH becomes synchronous with that of leptin. It was proposed that leptin may regulate the minute-tominute oscillations in the levels of $\mathrm{LH}$ and estradiol, and that leptin may in this way determine the change in LH profile preceding ovulation (31).

We found an association between serum leptin and LH concentrations when values recorded during different time points during the cycle were plotted with each other. The individual variability in the absolute levels of serum leptin concentrations and in the magnitude of changes in hormone concentrations led us to reanalyze the correlations using relative changes of the hormone concentrations. The weak but statistically significant association between serum leptin and LH seen in these analyses suggests that they may be linked with each other in humans. However, further studies are needed to show if this association represents a cause-and-effect relationship.

\section{Acknowledgements}

We are thankful to Ms Raija Kaartosalmi and Ms Elina Kahra for their skillful technical assistance. The financial support of the Jahnsson Foundation, Helsinki, Finland, is gratefully acknowledged.

\section{References}

1 Maffei M, Halaas J, Ravussin E, Pratley RE, Lee GH, Zhang Y et al. Leptin levels in human and rodent: measurement of plasma leptin 
and ob RNA in obese and weight-reduced subjects. Nature Medicine 19951 1155-1161.

2 Considine RV, Sinha MK, Heiman ML, Kriauciunas A, Stephens TW, Nyce MR et al. Serum immunoreactive-leptin concentrations in normal-weight and obese humans. New England Journal of Medicine $1996334292-295$.

3 Zhang Y, Proenca R, Maffei M, Barone M, Leopold L \& Friedman JM. Positional cloning of the mouse obese gene and its human homologue. Nature 1994327 425-432.

4 Swerdloff RS, Batt RA \& Bray GA. Reproductive hormonal function in the genetically obese $(\mathrm{ob} / \mathrm{ob})$ mouse. Endocrinology 197598 1359-1364.

5 Chehab FF, Lim ME \& Lu R. Correction of the sterility defect in homozygous obese female mice by treatment with the human recombinant leptin. Nature Genetics 199612 318-320.

6 Karlsson C, Lindell K, Svensson E, Bergh C, Lind P, Billig H et al. Expression of functional leptin receptors in the human ovary. Journal of Clinical Endocrinology and Metabolism 1997824144 4148.

7 Rosenbaum M, Nicolson M, Hirsch J, Heymsfield SB, Gallanger D, Chu F et al. Effects of gender, body composition, and menopause on plasma concentrations of leptin. Journal of Clinical Endocrinology and Metabolism 199681 3424-3427.

8 Saad MF, Damani S, Gingerich RL, Riad-Gabriel MG, Khan A, Boyadjian R et al. Sexual dimorphism in plasma leptin concentration. Journal of Clinical Endocrinology and Metabolism 199782 579-584.

9 Kennedy A, Gettys TW, Watson P, Wallace P, Ganaway E, Pan Q et al. The metabolic significance of leptin in humans: genderbased differences in relationship to adiposity, insulin sensitivity, and energy expenditure. Journal of Clinical Endocrinology and Metabolism 199782 1293-1300.

10 Widjaja A, Stratton IM, Horn R, Holman RR, Turner R \& Brabant G. UKPDS 20: plasma leptin, obesity and plasma insulin in type 2 diabetic subjects. Journal of Clinical Endocrinology and Metabolism $199782654-657$

11 Hickey MS, Israel RG, Gardiner SN, Considine RV, McCammon MR, Tyndall GL et al. Gender differences in serum leptin levels in humans. Biochemical and Molecular Medicine 199659 1-6.

12 Ostlund REJ, Yang JW, Klein S \& Gingerich R. Relation between plasma leptin concentration and body fat, gender, diet, age and metabolic covariates. Journal of Clinical Endocrinology and Metabolism $1996813909-3913$.

13 Zimmet P, Hodge A, Nicolson M, Staten M, de Courten M, Moore J et al. Serum leptin concentration, obesity and insulin resistance in Western Samoans: cross sectional study. British Medical Journal $1996313965-969$

14 Shimizu H, Shimomura Y, Nakanishi Y, Futawatari T, Ohtani K, Sato $\mathrm{N}$ et al. Estrogen increases in vivo leptin production in rats and human subjects. Journal of Endocrinology $1997154285-292$.

15 Hassink SG, Sheslow DV, de Lancey E, Opentanove I, Considine RV \& Caro JF. Serum leptin in children with obesity: relationship to gender and development. Pediatrics 199698 201-203.

16 Lahlou N, Landais P, De Boissieu D \& Bougneres P-F. Circulating leptin in normal children and during the dynamic phase of juvenile obesity. Diabetes 199746 989-993.
17 Montague CT, Prins JB, Sanders L, Digby JE \& O’Rahilly S. Depotand sex-specific differences in human leptin mRNA expression. Diabetes 199646 342-347.

18 Murakami T, Iida M \& Shima K. Dexamethasone regulates obese expression in isolated rat adipocytes. Biochemical and Biophysical Research Communications 1995214 1260-1267.

19 Slieker LJ, Sloop KW, Surface PL, Kriauciunas A, LaQuier F, Manetta J et al. Regulation of expression of ob mRNA and protein by glucocorticoids and cAMP. Journal of Biological Chemistry 1996 271 5301-5304.

20 Hardie L, Trayhurn P, Abramovich D \& Fowler P. Circulating leptin in women: a longitudinal study in the menstrual cycle and during pregnancy. Clinical Endocrinology 199747 101-106.

21 Licinio J, Mantzoros C, Negrao AB, Cizza G, Wong M-L, Bongiorno $\mathrm{PB}$ et al. Human leptin levels are pulsatile and inversely related to pituitary-adrenal function. Nature Medicine 19973 575-579.

22 Laughlin GA \& Yen SSC. Hypoleptinemia in women athletes: absence of a diurnal rhythm with amenorrhea. Journal of Clinical Endocrinology and Metabolism 199782 318-321.

23 Tataranni PA, Monroe MB \& Dueck CA. Adiposity, plasma concentration and reproductive function in active and sedentary females. International Journal of Obesity 199721 818-821.

24 Kuhl H, Jung-Hoffmann C \& Wiegratz I. Gestodene-containing contraceptives. Clinical Obstetrics and Gynecology 199538 829840 .

25 Kuhl H. Comparative pharmacology of newer progestogens. Drugs $199651188-215$

26 Kohrt WM, Landt M \& Birge SJJ. Serum leptin levels are reduced in response to exercise training, but not hormone replacement therapy, in older women. Journal of Clinical Endocrinology and Metabolism 199681 3980-3985.

27 Sainsbury A, Cusin I, Doyle P, Rohner-Jeanrenaud F \& Jeanrenaud B. Intracerebroventricular administration of neuropeptide $Y$ to normal rats increases obese gene expression in white adipose tissue. Diabetologia 199639 353-356.

28 Urban JH, Bauer-Dantoin C \& Levine JE. Neuropeptide Y expression in the arcuate nucleus: sexual dimorphism and modulation by testosterone. Endocrinology 1993132 139-145.

29 Yu WH, Kimura M, Walczewska A, Karanth S \& McCann SM. Role of leptin in hypothalamic-pituitary function. Proceedings of the National Academy of Sciences of the USA 199794 1023-1028.

30 Garcia-Mayor RV, Andrade A, Rios M, Lage M, Dieguez C \& Casanueva FF. Serum leptin levels in normal children: relationship to age, gender, body mass index, pituitary-gonadal hormones, and pubertal stage. Journal of Clinical Endocrinology and Metabolism 199782 2849-2855.

31 Licinio J, Negratildeo AB, Mantzoros C, Kaklamani V, Wong ML, Bongiorno PB et al. Synchronicity of frequently sampled, 24-h concentrations of circulating leptin, luteinizing hormone, and estradiol in healthy women. Proceedings of the National Academy of Sciences of the USA 199895 2541-2546.

Received 14 January 1998

Accepted 27 April 1998 